\title{
Aikuinen ja työ -opinnot \\ monimuotoisena ryhmäopiskeluna
}

\begin{abstract}
Kahden opintokeskuksen, Kansan Sivistystyön Liiton ja Työväen Sivistysliiton yhteinen kokeilu on nimeltään Aikuinen ja työ, käytössä AT-opinnot. Tarkoituksena on koota kolmen vuoden aikana tietoa ja kokemusta siitä, mitä merkitystä opiskelulle on sillä, että opiskelijat voivat itse vaikuttaa opintojensa sisältöjen valintaan ja niiden joustavuuteen. Kokeilun avainsanoja ovat sopimusopiskelu ja monimuoto-opetus. Kokeilun suunnittelu alkoi vuonna 1989 ja opiskelu päättyy syksyllä 91 .
\end{abstract}

Opiskelu on osanottajille ilmaista. Rahoitus muodostuu kouluhallituksen kokeilumäärärahasta, kurssien ja opintokerhojen valtionavusta sekä osanottajien SAK-laisten ammattiliittojen tuesta. Mukana ovat Kunnallisten työntekijäin ja viranhaltijain liitto KTV ja Metallityöväen liitto. Kokeilun sivutuotteena syntyy kuva opiskelukustannusten muodostumisesta ja muista opiskelun vaatimista voimavaroista.

\section{Opintosuunnitelma on sopimus}

Kokeilun lähtökohtana on sen järjestäjien näkökulmasta katsottuna selvittää, millaisia mahdollisuuksia opintokeskuksilla on järjestää aikuisväestölle pitkäkestoista ja vaatimuksiltaan korkeatasoista koulutusta. Tätä varten suunniteltiin työelämään liittyvä opintokokonaisuus, johon sisältyy avoimen korkeakoulun ja opintokeskusten laatimia opintoja. Opintojen alkupuolella opiskelu on ohjattua ja siinä käytetään kaikille yhteisiä sisältöjä ja suoritusvaatimuksia. Loppua kohti edettäessä opiskelijoiden valintamahdollisuudet lisääntyvät.

Opiskelijat laativat opintojensa alussa sopimuksen opintokeskusten ja oman ryhmänsä lemisesta yhdessä. Sopimus takaa yksittäiselle opiskelijalle "oikeuden" ryhmän jäsenyyteen ja opintojen jatkuvuuteen. Samalla ryhmien jäsenet laativat yhteiset pelisäännöt toimintaansa varten.

Yhteiseen opintojen perusosaan sisältyy johdatusta tietoon, aikuiskasvatukseen ja aikuiskoulutuksen psykologiaan sekä työelämään. Osa näistä opinnoista suoritetaan Helsingin yliopiston Lahden tutkimus- ja koulutuskeskuksen kanssa.

Toisen vuoden opinnot ovat valinnaisia. Opintokeskukset auttavat opiskelijoita valitsemaan itselleen sopivia opintoja. Valinnat voivat edistää ammattitaitoa ja työelämän tehtäviä, mutta myös harrastustavoitteinen opiskelu on mahdollista.

Yhteinen sopimus opintojen alussa velvoittaa myös opintokeskuksia olemaan opiskelijoiden tukena ja neuvonantajana. Pala palalta koostuva kokonaisuus osoittaa opiskelijoiden suuntautuneisuuden. Jokainen suoritettu osio arvioidaan ja merkitään opintokirjaan. Opiskelun päätyttyä suorituksista annetaan todistus AT-tutkinnon suorittamisesta. Se on vailla virallista statusta, mutta vastaa laajuudeltaan ja vaatimustasoltaan yliopiston approbatur-opintoja. 


\section{Ryhmän merkitys opinnoissa}

Vapaan sivistystyön perinteisiä työmuotoja on opiskelu pienryhmissä, opintokerhoissa. Tähän opiskelutapaan sisältyy omaehtoisuuden perusajatus. AT-kokeilussa opintokerho muodostaa keskuksen, josta opinnot haarautuvat itseopiskeluksi, lähiopiskeluksi kursseilla ja etäopinnoiksi.

Kokeilun avulla hankitaan tietoa siitä, mikä merkitys ryhmällä on opiskelun edistymiseen, tavoitteiden saavuttamiseen ja keskeyttämiseen. Erityisen tärkeä tämän seikan selvittäminen on, koska opintokerhoa usein epäillään

vanhanaikaiseksi työmuodoksi aikuiskasvatuksen piirissä.

Kokeiluun ilmoittautui kuusi ryhmää, joissa on 6-9 jäsentä. Yksi ryhmistä keskeytti työnsä perusopintojen jälkeen.

Ryhmät toimivat itsenäisinä siten, että ne valitsevat työtapansa ja aikataulunsa keskinäisten sopimustensa mukaisesti. Joku ryhmän jäsenistä toimii opintokerhon ohjaajana ja kirjeenvaihtajana. Jokaisella ryhmällä on opintokeskuksissa tutorinsa, joka on ryhmän käytössä oleva voimavara. Kokeilun avulla on mahdollista myös valaista tutorin merkitystä ryhmien työssä.

\section{Monimuotoisuus ja monivälineisyys opiskelun joustavuuden takeena}

AT-opintoryhmät opiskelevat oman työnsä ohessa. Se edellyttää opinto-ohjelmalta ajallista ja paikallistakin joustavuutta. Ryhmät laativat aikataulunsa yhteisten sopimusten mukaisesti. Tarkkoja määräaikoja ovat lähiopetusjaksot ja tenttipäivät.

Ryhmä muodostaa opintojen ytimen. Se toimii myös itseopiskelun välineenä siten, että jäsenet opettavat toinen toisiaan. Tässä toteutuu ajatus opettamalla oppimisesta.

Ryhmäopetusjaksot ovat viikonloppukursseja, joista tehdään yhteenvetoja opintojen kulusta ja suunnataan tuleviin jaksoihin. Samalla opiskelijat voivat vaihtaa kokemuksiaan ja opastaan toisiaan.
AT-kokeilussa opiskelijoille uutena välineenä käytetään sähköpostia. Jokaisella ryhmällä on käytössään teleboxiin perustettu ilmoitustaulutyyppinen tietokonekokous, jossa keskustellaan etäopettajan kanssa opittavasta asiasta ja oppimiseen liittyvistä kysymyksistä. Opettaja lähettää ryhmille tehtäviä, joihin opiskelijat vastaavat joko yhdessä ryhmänsä kanssa tai yksitellen.

Etäopettajan tehtävänä on ohjata ja auttaa tenttikirjojen lukemisessa ja ryhmien työskentelyssä. Palautteen antaminen on tehtävistä ehkä kaikkein merkittävin. Etäopettaja on opittavan asian asiantuntija, joka ohjaa käyttämään ja soveltamaan opittuja tietoja.

\section{Oppimisen päiväkirja dokumenttina tapahtuneesta}

Pääasiallisin menetelmä, jonka avulla kokeilun tulokset saadaan selville, on oppimisen päiväkirja. Jokainen opiskelija merkitsee muistiin oppimastaan ydinajatukset lyhyesti ja täsmällisesti. Samalla kirjataan kulloinenkin mieliala ja se mistä se johtuu. Päiväkirjaa on kehoitettu lukemaan esimerkiksi kerran kuukaudessa kokonaisuudessaan ja keskustelemaan ryhmässä kirjoittamisesta. Päiväkirjat ovat kuitenkin päiväkirjojen tapaan salaisia, itselle tehtyjä.

Myös tutoreilla on omat päiväkirjansa. $\mathrm{He}$ kirjaavat ajankäyttönsä, tekemänsä työt, ryhmän kanssa käymiensä keskustelujen sisältämät asiat, mielialansa ja kokemuksensa.

Päiväkirjamerkinnät muodostavat tärkeän tietolähteen kokeilun tuloksia laadittaessa. Opiskelijan näkökulmasta katsottuna opiskelun tarkoituksena on kehittää opiskeluvalmiuksia, lisätä työelämän tuntemusta ja ylläpitää jatkuvaa itsensä kehittämistä., Päiväkirjamerkinnät kertonevat paljon tästä kehityksestä.

\section{Loppupohdintaa}

Kokeilussa on monta juota niin kuin elämässä ja opiskelussa aina. Sopimusluonteisuus, tavoitteisuus opinnoissa, pitkäkestoisuus, omaehtoisuus, itsenäisyys, monimuotoisuus ja osallisuus ryhmässä. Kaikkia näitä lankoja koossa pitävänä yhdyssiteenä on opiskelumotivaatio. Tätä kirjoittaessani olen viisaasti ennustamatta julkisesti lopputulosta. Päiväkirjamerkintäni paljastavat aikanaan, millaiseksi sen ajattelin lokakuussa 1990. 